\title{
Brexit and public procurement: transitioning into the void?
}

\author{
Dr Pedro Telles ${ }^{*} \&$ Dr Albert Sanchez-Graells ${ }^{\dagger}$
}

\section{ABSTRACT}

On 29 March 2017, the UK notified its intention of leaving the EU. This activated the two-year disconnection period foreseen in Article 50 TEU, thus resulting in a default Brexit at the end of March 2019. The firming up of a draft agreement on a transition period to run until 31 December 2020 could provide a longer timescale for the Brexit disconnection, as well as some clarity on the process of disentanglement of the UK's and EU's legal systems. The draft transition agreement of 19 March 2018, updated on 19 June 2018 and still under negotiation at the time of writing (August 2018), provides explicit rules on public procurement bound to regulate 'internal' procurement trade between the UK and the EU for a period of over 15 months. However, the uncertainty concerning the future EU-UK relationship remains, and the draft agreement does not provide any indication on the likely legal architecture for future EU-UK trade, including through public procurement. The draft agreement has thus not suppressed the risk of a 'cliff-edge' disconnection post-Brexit, but rather solely deferred it. The transition is currently not into an alternative system of procurement regulation, but rather into the void. There have also been very limited developments concerning the UK's and EU's repositioning within the World Trade Organisation Government Procurement Agreement (WTO GPA), which creates additional legal uncertainty from the perspective of 'external' trade in procurement markets due to the absence of a 'WTO rules' default

\footnotetext{
* Senior Lecturer, College of Law and Criminology, Swansea University and Adjunct at the Law Futures Centre, Griffith University.p.telles@swansea.ac.uk. Member of the Law Society’s European Union Committee. Author of the blog http://www.telles.eu/.

${ }^{+}$Reader in Economic Law, University of Bristol Law School. a.sanchez-graells@bristol.ac.uk. Member of the European Commission's Stakeholder Expert Group on Public Procurement (2015/18). Author of the blog http://www.howtocrackanut.com/.
} 
applicable to public procurement. Against the backdrop of this legal uncertainty, this paper critically assesses the implications of the 2018 draft transition agreement, both for the re-regulation of 'internal' EU-UK procurement, and for the re-positioning of both the EU and the UK within the WTO GPA, as the basis for their 'external' procurement trade with third countries. The paper concludes that it is in both the UK's and the EU's interest to reach a future EU-UK FTA that ensures continued collaboration and crystallises current compliance with EU rules, and to build on it to reach a jointly negotiated solution vis-a-vis the rest of WTO GPA parties. The paper constitutes a detailed case study that provides insights applicable to other areas of Brexit-related trade re-regulation.

\section{KEYWORDS}

Brexit, Public Procurement, Government Procurement Agreement, GPA, UK, EU, Regulatory Reform, International Trade, Free Trade Agreements, Liberalisation, Convergence, Technical Cooperation

\section{JEL CODES}

F13, H57, K23, K42, P45 


\section{Introduction}

As is well-known, ${ }^{1}$ after an EU membership referendum in June 2016 that resulted in a thin 52/48 majority vote to leave the Union and triggered protracted domestic litigation on the constitutional requirements applicable to the official notification of that result; ${ }^{2}$ on 29 March 2017, the UK notified its intention to leave the EU. ${ }^{3}$ This activated the two-year disconnection period foreseen in Article 50 TEU, ${ }^{4}$ thus resulting in a default Brexit at the end of March $2019 .{ }^{5}$ It also resulted in significant legal uncertainty leading to potentially very negative economic impacts, both from an 'internal' perspective (ie EU-UK trade) and an 'external' perspective (involving trade with the rest of the world by both the EU and the UK). Such uncertainty and potential breakdown of existing economic and trade

Note: all websites last accessed 14 August 2018.

${ }^{1}$ An exploding literature on Brexit provides detailed insights on the background to the referendum, the potential reasons for the vote to leave the EU, as well as analysis of open questions about the organisation and funding of the political campaigns and other interesting issues. However, the purpose of this paper is to limit the discussion to the field of public procurement. Therefore, to keep it manageable, we will not include references to more general issues, except where strictly necessary.

${ }^{2}$ See $R$ (on the application of Miller and another v Secretary of State for Exiting the European Union [2017] UKSC 5 (24 January 2017).

3 The notification was given in exercise of the powers created by the European Union (Notification of Withdrawal) Act 2017, 2017 c. 9.

${ }^{4}$ Consolidated version of the Treaty on European Union [2012] C 326/13, Art. 50(3).

${ }^{5}$ Its consequences are clearly spelled-out in this brief European Commission Notice to Stakeholders, Withdrawal of the United Kingdom and EU rules in the field of public procurement, 18 January 2018, available at https://ec.europa.eu/docsroom/documents/27347. See A Sanchez-Graells, 'Post-Brexit Procurement: New European Commission (Short) Guidance, and Some Broader Thoughts', howtocrackanut blog, 19 January 2018, http://www.howtocrackanut.com/blog/2018/1/19/european-commission-short-guidance-on-post-brexitprocurement-and-some-broader-thoughts. 
relationships was quickly evidenced in the area of public procurement (or government contracts), probably due to the politically-charged use of public contracts for protectionist purposes to which both the UK and the EU can feel tempted. ${ }^{6}$ Indeed, Brexit could largely undo the work of over forty years in creating a single procurement market, where Member States are not allowed to favour their domestic suppliers for goods, services and works. ${ }^{7}$ Under EU public procurement law, ${ }^{8}$ Member States

\footnotetext{
${ }^{6}$ For example, concerning the procurement of advisory services for the UK government, see A Sanchez-Graells, “"Buy Brexit"? Using "cultural fit" as evaluation criteria breaches EU and UK public procurement law', PolicyBristol blog, 2 March 2017, available at https://policybristol.blogs.bris.ac.uk/2017/03/02/buy-brexit-
} using-cultural-fit-as-evaluation-criteria-breaches-eu-and-uk-public-procurement-law/. On the other side, on eg a potentially too-strict approach to pre-award screening of access to procurement contracts with a duration beyond Brexit, see M Leroux, 'Macron wants British firms frozen out of EU contracts', The Times, 9 May 2017, available at https://www.thetimes.co.uk/article/macron-wants-british-firms-frozen-out-of-eu-contractsr09wtwwpg. Most recently, and not without an element of irony, the procurement of the post-Brexit new UK passports has spurred additional controversy, see H Stewart \& K Rawlinson, 'Post-Brexit passports set to be made by Franco-Dutch firm', available at https://www.theguardian.com/politics/2018/mar/22/post-brexitpassports-set-to-be-made-by-franco-dutch-firm, on which see $\mathrm{P}$ Telles, 'Timely reminder public procurement rules still apply in the UK', Telles.eu blog, 22 March 2018, http://www.telles.eu/blog/2018/3/22/timelyreminder-public-procurement-rules-still-apply-in-the-uk.

7 This has been the core goal of EU public procurement law. Cfr S Arrowsmith, 'The Purpose of the EU Procurement Directives: Ends, Means and the Implications for National Regulatory Space for Commercial and Horizontal Procurement Policies' (2011-2012) 14 Cambridge Yearbook of European Legal Studies 1-47.

8 The current 2014 EU public procurement package is comprised of Directives 2014/23/EU on concession contracts (OJ 2014 L94/1), 2014/24/EU on public sector procurement (OJ 2014 L94/65) and 2014/25/EU on utilities procurement (OJ 2014 L94/243). There are additional regulatory instruments, such as Directive 2009/81/EC on defence and security procurement (OJ 2009 L216/76) and Directives 89/665/EEC and 92/13/EEC on procurement remedies (both amended by Directive 2007/66/EC, OJ 2007 L335/31). These rules apply to procurement carried out by the Member States. The procurement of the EU Institutions is subjected to similar 
cannot discriminate between economic operators on grounds of nationality, either directly or indirectly (eg by imposing contractual requirements that result in de facto discrimination). ${ }^{9}$ This simple principle would be threatened if, in the context of Brexit, the UK and the EU re-erected barriers in procurement markets as part of the unravelling of their trade relationships. In 2015, the UK's public procurement market was valued at over $£ 260$ billion, and the total public procurement market in the EU was worth $£ 1.5$ trillion. ${ }^{10}$ Thus, a deterioration of the reciprocal EU-UK access to procurement markets could have significant negative economic impacts.

Given the legal uncertainty and economic instability generated by the activation of Article 50 TEU, this soon led to intense negotiations of a withdrawal agreement between the UK and the EU, ${ }^{11}$ which culminated in December 2017 in a 'phase one' agreement in principle on the main consequences of the loss of EU membership by the UK. ${ }^{12}$ 'Phase two' of the negotiations kicked-off in

rules in a different set of regulations that is bound to be replaced from 1 January 2019 by the recently adopted 'Omnibus Regulation' on the financial rules applicable to the general budget of the Union (OJEU publication pending), available at http://data.consilium.europa.eu/doc/document/PE-13-2018-INIT/en/pdf. The implementation of procurement procedures is supported by the adoption of a common procurement vocabulary (CPV), which is established in Regulation (EC) No 2195/2002 (OJ 2002 L 340/1).

${ }^{9}$ For a recent procurement case based on the prohibition of discrimination on grounds of nationality, see the Judgment of 19 April 2018, Oftalma Hospital, C-65/17, EU:C:2018:263.

10 Institute for Government, Public Procurement Explainer, available at https://www.instituteforgovernment.org.uk/explainers/public-procurement.

${ }^{11}$ For an assessment of the early stages, see our P Telles \& A Sanchez-Graells, 'Examining Brexit Through the GPA's Lens: What Next for UK Public Procurement Reform?' (2017) 47(1) Public Contract Law Journal 1-33.

12 Joint report from the negotiators of the European Union and the United Kingdom Government on progress during phase 1 of negotiations under Article 50 TEU on the United Kingdom's orderly withdrawal from the European Union. TF50 (2017) 19 - Commission to EU 27, 8 December 2017, available at https://ec.europa.eu/commission/sites/beta-political/files/joint report.pdf. 
January 2018 and quickly involved the explicit recognition of the need for a transition period to avoid the legal uncertainties and potentially very damaging economic impacts of a 'cliff-edge' disconnection of the two legal systems. ${ }^{13} \mathrm{~A}$ draft agreement on a transition period was published on 19 March $2018,{ }^{14}$ in which the EU and the UK reached provisional agreement on a large number (but not all) of the issues relevant for its implementation. Some of the open issues were further agreed in an updated version of the draft transition agreement published on 19 June 2018 (the DTA), ${ }^{15}$ and the EU and the UK continue negotiating at the time of writing (August 2018).

If finally agreed, the DTA will establish a transition period to run (at least) until 31 December 2020, which will provide a longer timescale for the Brexit disconnection, as well as some clarity on the process of disentanglement of the UK's and EU's legal systems. The DTA provides explicit rules on public procurement ${ }^{16}$ bound to regulate 'internal' procurement trade between the UK and the EU for a period of over 15 months, ${ }^{17}$ thus preventing protectionist procurement practices during this period.

${ }^{13}$ See UK Parliament House of Commons, European Scrutiny Committee, Report on Public Procurement, 19 December 2017, available at https://publications.parliament.uk/pa/cm201719/cmselect/cmeuleg/301vii/30108.htm.

${ }^{14}$ Draft Agreement on the withdrawal of the United Kingdom of Great Britain and Northern Ireland from the European Union and the European Atomic Energy Community highlighting the progress made (coloured version) in the negotiation round with the UK of 16-19 March 2018. TF50 (2018) 35 - Commission to EU27, 19 March 2018, available at https://ec.europa.eu/commission/sites/beta-political/files/draft agreement coloured.pdf.

${ }^{15}$ Joint statement from the negotiators of the European Union and the United Kingdom Government on progress of negotiations under Article 50 TEU on the United Kingdom's orderly withdrawal from the European Union. TF50 (2018) 52 - Commission to EU 27, 19 June 2018, available at https://ec.europa.eu/commission/sites/betapolitical/files/joint statement.pdf.

${ }^{16}$ See TITLE VIII - Ongoing Public Procurement and Similar Procedures, Arts. 71-74.

${ }^{17}$ Even if, unless otherwise extended, the transition period will end on 31 December 2020, some of the rules on public procurement are bound to create effects beyond that cut-off date, as discussed below (section 2). 
However, the uncertainty concerning the future EU-UK relationship remains, and the draft agreement does not provide any indication on the likely legal architecture for future EU-UK trade, including through public procurement. ${ }^{18}$ The draft agreement has thus not suppressed the risk of a 'cliff-edge' disconnection post-Brexit, but rather simply deferred it. The risk of a rekindling of the protectionist award of public contracts as a mechanism of industrial policy is therefore still on the table. More generally, there is a significant number of issues that require further thought and negotiation to ensure a smooth transition into an effective mechanism for continued 'frictionless trade' between the EU and the UK (including in procurement markets) from 1 January 2021-in particular given the growing realisation that the rules of the World Trade Organisation (WTO) do not provide a satisfactory 'WTO default' that could avoid the disruption generated by a 'no deal' Brexit. ${ }^{19}$

The abovementioned uncertainties surrounding the bilateral regulation of 'internal' procurement trade between the EU and the UK are compounded by the existence of an additional layer of international trade law that regulates their 'external' procurement relationships with the rest of the world. Differently from other areas of trade covered by WTO rules-which are regulated by multilateral agreements (like the GATT or the GATS)-procurement is regulated by a sui generis plurilateral agreement on government procurement (the WTO GPA). ${ }^{20}$ Not all WTO members are parties to the WTO GPA, and those that are parties operate a system of reciprocally-open government

${ }^{18}$ On the different options available, see eg S Arrowsmith, 'The Implications of Brexit for Public Procurement Law and Policy in the United Kingdom' (2017) 1 Public Procurement Law Review 1-33; and ibid, Consequences of Brexit in the Area of Public Procurement, Report for the European Parliament, IP/A/IMCO/2016-23 (2017), available at http://www.europarl.europa.eu/RegData/etudes/STUD/2017/602028/IPOL_STU(2017)602028 EN.pdf.

${ }^{19} \mathrm{~F}$ Baetens, “"No deal is better than a bad deal”? The fallacy of the WTO fall-back option as a post-Brexit safety net' (2018) 55(2/3) Common Market Law Review 133-174.

20 Revised Agreement on Government Procurement (2012, effective 2014), available at https://www.wto.org/english/tratop_e/gproc e/gp gpa e.htm. 
procurement markets on the basis of bilaterally negotiated schedules of coverage. Currently, the procurement relationships of both the EU and the UK with the rest of WTO GPA countries are covered by a single set of schedules negotiated by the EU on behalf of all its Member States-which are not themselves parties to the WTO GPA. Brexit thus requires both the EU and the UK to adjust their position under the WTO GPA. The EU must adjust its schedules of coverage and the UK must seek fresh accession to the WTO GPA in its own right. This creates additional legal uncertainty from the perspective of 'external' trade in procurement markets, ${ }^{21}$ particularly due to the absence of a 'WTO rules' default applicable to procurement-related trade. To date (August 2018), there have been very limited developments concerning the UK's and EU's repositioning within the WTO GPA. As with the rest of their WTO commitments, the UK and the EU have adopted a joint approach towards the 'adjustment' or 'splitting up' of their currently joint commitments under the WTO GPA, by committing to 'maintain the existing levels of market access available to other WTO Members', including under the WTO GPA. ${ }^{22}$ On 5 June 2018, the UK applied for individual accession to the WTO GPA. ${ }^{23}$ The UK's application evidenced the EU-UK joint front strategy, although the EU reserved its position on the terms of the UK's final market access offer. On 27 June 2018, the WTO government procurement committee noted the UK's application but sought additional information. In particular, WTO GPA 'parties sought more information on [the UK's] market access commitments, its EU withdrawal agreement, including timelines that would apply to the GPA, and its plans for domestic procurement

\footnotetext{
${ }^{21}$ See P Wang, 'Brexit and the WTO Agreement on Government Procurement' (2017) 47(1) Public Contract Law Journal 34-61; C Yukins, 'Brexit and procurement: a US perspective on the way ahead' (2017) 47(1) Public Contract Law Journal 71-75; Telles \& Sanchez-Graells (n 11).

22 Joint letter of the EU and UK permanent representatives to the World Trade Organization, 11 October 2017, available at https://ec.europa.eu/commission/sites/betapolitical/files/letter_from eu and uk permanent representatives.pdf.

${ }^{23}$ See J Heilman Grier, 'Britain Applies for GPA Membership', Perspectives on Trade, 6 June 2018, available at https://trade.djaghe.com/?p=4894.
} 
legislation' ${ }^{24}$ This clearly reflects the fact that the readjustment of the EU and the UK's 'external procurement' under the WTO GPA is dependent on their bilateral agreement for future 'internal' EUUK procurement-related trade. It also indicates that there will be a need for further negotiations with other WTO GPA members, and that these could take time to complete. Thus, it is as yet unclear whether it will be possible to reach a legal position that avoids disruption of international supply chains in UK (and to some extent EU) public procurement markets from 1 January 2021-and any such position will largely hinge on the EU-UK agreement, not only of the DTA, but also of a framework for the future EU-UK trade relationship.

With these complexities as background, the main goal of this paper is to assess the progress achieved to date in the re-regulation of post-Brexit procurement-related trade, and to map the issues that require further work in the run up to 'effective Brexit' on 1 January 2021. To do so, this paper critically assesses the implications for public procurement of the March 2018 DTA, as updated in June 2018. In particular, the paper identifies three shortcomings that would have required explicit regulation: first, the exclusion from the scope of coverage of the DTA of procurement carried out by the EU Institutions themselves; second, the continued enforcement of the rules on contract modification and termination; and third, the interaction between procurement and other rules (section 2). The paper also flags up some of the areas for future EU-UK collaboration that require attention beyond the hints that can be extracted from the DTA (section 3). The paper then goes on to revisit the continued uncertainty concerning the EU's and UK's position within the WTO GPA (section 4). It concludes that it is in both the UK's and the EU's interest to reach a future EU-UK FTA that ensures continued collaboration and crystallises current compliance with EU rules, and to build on it to reach a jointly negotiated solution vis-a-vis the rest of WTO GPA parties (section 5). The paper thus

\footnotetext{
${ }^{24}$ See J Heilman Grier, "WTO GPA Update \#10: Accession Negotiations', Perspectives on Trade, 2 July 2018, available at https://trade.djaghe.com/?p=4934.
} 
constitutes a detailed case study that provides insights applicable to other areas of Brexit-related trade re-regulation.

\section{Transition Period 'Internal' EU-UK Procurement: Business as Usual?}

As mentioned above, and as part of the 'phase two' Brexit negotiations, the EU and the UK concentrated on the design of rules applicable to a transition period towards full effectiveness of the UK's withdrawal from the Union and its loss of the condition of Member State. Given that every year over 250,000 public authorities in the EU spend around 14\% of GDP on the purchase of services, works and supplies, ${ }^{25}$ and that bilateral UK-EU procurement-related trade can be estimated at around $15 \%$ of the total value of procurement, or close to $2.5 \%$ of $\mathrm{GDP},{ }^{26}$ phase two Brexit negotiations included procurement as one of their priorities. The EU had published an early position paper on on-going procurement procedures in September 2017, ${ }^{27}$ which formed the basis for initial discussions during phase two. Public procurement issues were explicitly addressed in the initial draft transition agreement prepared by the European Commission, ${ }^{28}$ triggered further analysis in a position paper by

25 European Commission, Public procurement strategy, available at https://ec.europa.eu/growth/singlemarket/public-procurement en.

${ }^{26}$ Based on the written evidence submitted by Sanchez-Graells to the to the House of Lords EU Internal Market Sub-Committee, as reflected in the House of Commons European Scrutiny Select Committee's Report on Public Procurement of 19 December 2017, available https://publications.parliament.uk/pa/cm201719/cmselect/cmeuleg/301-vii/30108.htm.

27 Position paper on On-going Public Procurement Procedures. TF50 (2017) 12/2 - Commission to UK, 20 September 2017, available at https://ec.europa.eu/commission/sites/betapolitical/files/public procurement.pdf.

${ }^{28}$ European Commission Draft Withdrawal Agreement on the withdrawal of the United Kingdom of Great Britain and Northern Ireland from the European Union and the European Atomic Energy Community. TF50 (2018) 33 - 
the UK Government, ${ }^{29}$ and ultimately featured rather prominently in the provisionally agreed 19 March 2018 DTA, ${ }^{30}$ which however left open issues concerning procurement enforcement procedures and the application of the principle of non-discrimination The further negotiations leading to the updated 19 June 2018 DTA brought agreement on those outstanding issues. ${ }^{31}$ At the time of writing (August 2018), all procurement rules in the DTA are provisionally jointly agreed by the EU and the UK.

The point of departure (or status quo pre-Brexit) is that the award by the Member States of contracts above certain value thresholds is subject to the detailed rules of EU public procurement

Commission to EU 27, 28 February 2018, available at https://ec.europa.eu/commission/sites/betapolitical/files/draft withdrawal agreement.pdf. For contemporary analysis, see P Telles, 'Some thoughts on the procurement elements of the EU's Draft Withdrawal Agreement', Telles.eu blog, 28 February 2018, http://www.telles.eu/blog/2018/2/28/some-thoughts-on-the-procurement-elements-of-the-eus-draftwithdrawal-agreement.

29 HM Government, Technical Note: Other Separation Issues - Phase 2, available at https://www.gov.uk/government/uploads/system/uploads/attachment data/file/685748/Other Separation I ssues Technical note March 2018.pdf. For contemporary analysis, see P Telles, 'The UK Technical Note on Other Separation Issues [Public Procurement]', Telles.eu blog, 6 March 2018, http://www.telles.eu/blog/2018/3/6/the-uk-technical-note-on-other-separation-issues-public-procurement. ${ }^{30}$ See nn 14 \& 16 above. For discussion, see P Telles, 'Updated Draft Agreement on the UK's withdrawal from the EU [Public Procurement]', Telles.eu blog, 21 March 2018, http://www.telles.eu/blog/2018/3/21/updateddraft-agreement-on-the-uks-withdrawal-from-the-eu-public-procurement.

${ }^{31}$ See n 15. 
law, ${ }^{32}$ as transposed into the domestic legal order of the Member States..$^{33}$ Moreover, even contracts of a lower value that have a 'certain cross-border interest' are subjected to requirements derived from the general principles of EU law and, in particular, the principle of non-discrimination on grounds of nationality. ${ }^{34}$ All procurement decisions are susceptible of challenge before domestic courts and review bodies under special procedures regulated by additional EU rules on remedies. ${ }^{35}$ The procurement of the EU Institutions (ie that directly funded by the EU budget) is subject to separate but similar rules, ${ }^{36}$ and their procurement decisions can be challenged in front of the Court of Justice. Therefore, to ensure continuity of the status quo during a transition agreement, it would be necessary to at least guarantee the continued effectiveness of substantive and procedural EU procurement rules, including those applicable to the EU Institutions, as well as the broader application of the principle of non-discrimination or equal treatment-and to ensure the justiciability of those rules through adequate remedies. Given that procurement procedures tend to last a few months (depending on

\footnotetext{
32 See $n$ 8. Currently, the detailed rules of Directives 2014/23, 2014/24, 2014/25 and 2009/81 apply for contracts above the thresholds established by the European Commission, available at
} https://ec.europa.eu/growth/single-market/public-procurement/rules-implementation/thresholds en.

${ }^{33}$ Transposition is necessary, given that EU procurement law takes the form of Directives (n 8). As per general requirements of EU law, of course, the transposition is subject to the principles of direct effect and the duty of consistent interpretation, so any discrepancy between the domestic transposition and the EU rules needs to be resolved in a way that ensures the effectiveness of EU public procurement law.

34 The applicable test has recently been recast in the Judgment of 6 October 2016, Tecnoedi Costruzioni, C318/15, EU:C:2016:747. For extended discussion of the requirements derived from general principles in relation to contracts not covered by the EU directives, see C Risvig Hamer (ex Risvig Hansen), Contracts not covered or not fully covered by the Public Sector Directive (Copenhagen, DJøF Publishing, 2012).

\footnotetext{
${ }^{35}$ In particular the requirements introduced by Directive 2007/66/EC. See n 8 .

${ }^{36}$ From 1 January 2019, the newly adopted Omnibus Regulation. See n 8.
} 
their complexity, they can easily go up to almost a year), establishing transitional rules requires considering this temporal dimension of procurement transactions.

In order to regulate the 'disconnection' of UK procurement from EU rules and the readjustment of UK access to EU procurement markets, the DTA concentrates on on-going procurement procedures at the time of Brexit and aims for a phased disapplication of EU law to public procurement carried out by the UK authorities after that date, as well as a phased exclusion of UK tenderers from within the pool of beneficiaries of market access under the EU public procurement rules (subject to the application of the principle of non-discrimination, as discussed below). In order to establish operational rules, the DTA defines the scope of EU public procurement law for its own purposes (Art 71) and sets out rules applicable to ongoing procedures (Art 72), enforcement procedures (Art 73) and selected issues of continued cooperation (Art 74). This section critically assesses the procurement Title of the DTA, both in terms of the explicit rules it contains (2.1) and some shortcomings that can create legal difficulties during the transition period and beyond (2.2).

\subsection{What the DTA covers: aiming for business as usual}

First and foremost, the DTA aims to ensure the continued application of substantive EU public procurement law, including the requirements derived from general principles. To that effect, Art 71 DTA defines the "relevant rules" to which the transition agreement will apply. Notably, these cover the entire suit of substantive procurement directives: the 2014 EU public procurement package and the earlier 2009 directive on defence and security procurement, as well as the regulation on the Common Procurement Vocabulary that underpins their operation, ${ }^{37}$ and (even if potentially more difficult to apply in this context) "the general principles of Union law applicable to the award of public

\footnotetext{
${ }^{37}$ There are other procurement-like sectoral rules included in Article 71 DTA, but these are not relevant for the purposes of our discussion. Thus, our considerations are limited to the applicability of Directives 2009/81/EC, 2014/23/EU, 2014/24/EU and 2014/25/EU, as well as Regulation 2195/2002/EC. See n 8.
} 
contracts". This is important because Art 72 DTA establishes the continued application of the "relevant rules" to ongoing procedures (in the terms discussed below), which arguably creates an explicit legal basis for the continued effectiveness of general principles of EU public procurement law regarding 'contracts of a certain cross-border interest' not otherwise covered by the EU procurement directives. ${ }^{38}$ It is not irrelevant that the DTA refers to the application of EU public procurement law ${ }^{39}$ and not to its transposition in the UK, ${ }^{40}$ as this would imply the possibility of continued override of any faulty UK transposition (notably, in the Public Contracts Regulations $2015^{41}$ ) under the general EU law doctrines of direct effect and consistent interpretation. Furthermore, it also ensures the possibility for requests for preliminary rulings on the interpretation of the $2014 \mathrm{EU}$ public procurement package rules during the transition period. This, however, will be subject to Title X DTA on 'Union judicial and administrative procedures', which is currently not agreed. ${ }^{42}$

${ }^{38}$ This is, indeed, the contextual reading of the set of rules in the DTA. An alternative reading could try to restrict the applicability of the general principles to procurement covered by the rest of the "relevant rules", but this seems difficult to support; see Telles, 'Updated Draft Agreement on the UK's withdrawal from the EU [Public Procurement]' (n 30). See n 34 .

${ }^{39}$ Including "any other specific rules of Union law governing public procurement procedures", which creates an open-ended approach aimed at ensuring inclusiveness of any procurement-relevant rules not mentioned nominatim or expressis verbis in Art 71 DTA.

${ }^{40}$ See $n$ 33. See also Telles, 'The UK Technical Note on Other Separation Issues [Public Procurement]' (n 29). On the transposition of the 2014 Public Procurement Package, see A Sanchez-Graells, 'The Implementation of Directive 2014/24/EU in the UK'", in S Treumer \& M Comba (eds), Modernising Public Procurements: The Approach of Member States, vol. 8 European Procurement Law Series (Edward Elgar, 2018) 277-306.

${ }^{41}$ SI 2015 No. 102. Generally, see P Telles \& A Sanchez-Graells, Public Contracts Regulations Commentary, available at http://pcr2015.uk/.

${ }^{42}$ See e.g. the comments on the DTA by the Law Society of Scotland (29 March 2018) available at https://www.lawscot.org.uk/media/359941/law-society-of-scotland-version6.pdf. See also the Research 
Another issue of potential contention regarding general principles of EU procurement law concerns the interpretation of the principle of non-discrimination under Art 72(2) DTA. This paragraph establishes that 'without prejudice to the application of any restriction in accordance with Union law, the non-discrimination principle shall be complied with by contracting authorities and contracting entities with regard to tenderers or, according to the relevant rules, persons entitled to otherwise submit applications, from the Member States and the United Kingdom in relation to the procedures referred to in paragraph $1^{\prime}$ of that same Art 72 DTA. This provision is strange and seemingly superfluous because Art 71 DTA includes "the general principles of Union law applicable to the award of public contracts" amongst the "relevant rules"-which clearly comprises the principle of nondiscrimination on the basis of nationality ${ }^{43}$ and Art 72(1) DTA establishes the scope of applicability of those rules in manner that is unchanged by the cross-reference in Art 72(2) DTA. Therefore, it is difficult to see what would be the additional functionality of the latter provision.

In order to create temporal consistency and legal certainty, Art 72 DTA aims to establish and operationalise the principle of 'initially subject, always subject' to the "relevant rules". Indeed, according to Art 72(1)(a) DTA, those "relevant rules" will be applicable to any procedures launched by contracting authorities or contracting entities from the Member States or the UK before the end of the transition period and not yet finalised at the end of the transition period-ie on 31 December 2020 or any later date, in case of an extension of the transition period. This applies to all types of procurement procedures (ie it includes procedures using dynamic purchasing systems as well as procedures for which the call for competition takes the form of a prior information notice or periodic indicative notice or a notice on the existence of a qualification system). The trigger for the application

Briefing of the Library of the House of Commons, Brexit: the draft withdrawal agreement (26 March 2018) available at https://researchbriefings.parliament.uk/ResearchBriefing/Summary/CBP-8269.

${ }^{43}$ This is constant jurisprudence in the case law of the Court of Justice of the European Union. Most recently, see Judgment of 8 February 2018, Lloyd's of London, C-144/17, EU:C:2018:78, paragraph 23. 
of the EU rules to a given procedure is its launch before the end of the transition period, and that application remains unaffected by the expiry of the transition period, carrying through to the end of the procedure.

Framework agreements ${ }^{44}$ are also covered by Art 72 DTA under the same principle of 'initially subject, always subject' to the "relevant rules". Art 72(1)(b) DTA establishes special rules for the award of contracts within framework agreements (ie relating to their performance), whereby EU rules will not only apply to framework agreements concluded before the end of the transition period that, as of that date, have neither expired nor been terminated (ie 'live' framework agreements), but also to framework agreements concluded after the end of the transition period as a result of a procedure covered by Art 72(1)(a) DTA (ie 'launched' framework agreements). Given that the maximum duration of a framework agreement should not ordinarily exceed four years, ${ }^{45}$ and the principle of 'initially subject, always subject', this could potentially require continued compliance with EU public procurement law for four years post-Brexit in relation to the call-offs within launched framework agreements. Of course, this could generate some strategic behaviour from contracting authorities or entities towards the end of the transition period (eg withholding of calls for tenders for new framework agreements close to the end of the transition period or early termination of existing framework agreements 'for convenience' after that date), but this seems difficult to avoid through legal rules-other than through the general anti-circumvention provisions of the "relevant rules"

\footnotetext{
${ }^{44} \mathrm{~A}$ framework agreement means an agreement between one or more contracting authorities and one or more economic operators, the purpose of which is to establish the terms governing future contracts to be awarded during a given period, in particular with regard to price and, where appropriate, the quantity envisaged. The award of contracts within a framework agreement (or call-offs) can be either in the terms specified in the framework agreement itself, or in the terms that result from a 'mini-competition'. See Art 33 Dir 2014/24/EU.

${ }^{45}$ Art 33(1)II Dir 2014/24/EU; reg 33(3) PCR2015.
} 
themselves ${ }^{46}$ This triggers the same issues of on-going monitoring of the potential modification and termination of contracts discussed below (see section 2.2).

Given the importance of launch and finalisation dates for the operationalisation of the 'initially subject, always subject' principle, it is not surprising that these are regulated in Art 72 DTA. Articles 72(3) and (4) establish explicit rules depending on whether notices and other transparency requirements are required by the "relevant rules" ${ }^{47}$ Where such notices are required, Art 72(3) DTA deems a procedure launched when a call for competition or any other invitation to submit applications has been made in accordance with the "relevant rules", and Art 72(4) considers the procedure finalised upon publication of a contract award notice in accordance with the "relevant rules". This is a rather straightforward if formalistic approach that does not seem to leave scope for doubt or misinterpretation. Where a contract notice is not required under the "relevant rules", Art 72(3) DTA considers the procedure launched when the contracting authority has contacted economic operators in relation to that contract opportunity. In turn, where the "relevant rules" do not require the publication of a contract award notice, Art 72(4)(a) DTA deems a procedure finalised upon conclusion of the relevant contract. This aims to provide a practical trigger for the applicability of EU rules to these less than fully transparent procedures, which can however raise practical difficulties (as discussed below). In addition to these rules, and of high potential practical relevance in view of the

${ }^{46}$ Eg Art 5 Dir 2014/24/EU; reg 5 PCR2015.

${ }^{47} \mathrm{EU}$ procurement law imposes a variety of transparency requirements to promote competition for public contracts and to facilitate the enforcement of tenderers' rights. The most important transparency requirements are structured around notices to advertise contract opportunities and to call for competition (contract notices and, in some case, prior information notices) and notices to advertise the result of procurement procedures (contract award notices). Some types of contracts (eg those directly awarded on the basis of technical or legal exclusivity) do not require the publication of notices. Where required, the relevant notices need to be published in the Official Journal of the European Union, through the specialised Tenders Electronic Daily (TED). This is regulated in detail, eg Arts 48 to 52 Dir 2014/24/EU. TED is accessible at https://ted.europa.eu/. 
risk of strategic behaviour close to the date of 'effective Brexit' identified above, Art 72(4)(b) DTA also includes a provision concerning cancelled or abandoned procurement procedures. These will be considered finalised upon informing tenderers or, according to the "relevant rules", persons entitled to otherwise submit applications, of the reasons why the contract was not awarded. ${ }^{48}$ This approach of course generates the practical difficulty of potential direct awards in breach of the "relevant rules", as well as the difficulties in the simple de facto abandonment of an ongoing procurement procedure. In that regard, the DTA rules are no better or worse than the general EU procurement rules-which enforcement and effectiveness are vulnerable to difficulties in the observation of breaches where transparency obligations are ignored or abused. These are issues closely linked to the possibility of launching enforcement procedures, which is regulated in Art 73 DTA.

Art 73 DTA establishes the application of EU public procurement remedies directives ${ }^{49}$ in the public procurement procedures covered by Art 72 DTA and falling within the scope of those directives. This seems straightforward, but its effective implementation will be highly dependent on the still pending agreement on the jurisdiction of the Court of Justice of the European Union, ${ }^{50}$ even if the application of the remedies directives is incumbent upon the domestic courts-subject only to obligations concerning preliminary references on which, as mentioned above, there is no agreement yet.

Finally, Art 74 DTA aims to ensure continued partial cooperation between the UK and the EU in measures aimed at facilitating cross-border participation in procurement procedures and the

\footnotetext{
48 Under the relevant rules, contracting authorities have to inform as soon as possible each candidate and tenderer of decisions not to award a contract for which there has been a call for competition, to recommence the procedure or not to implement a dynamic purchasing system. See eg Art 55(1) Dir 2014/24.

${ }^{49}$ Directives 89/665/EEC and 92/13/EEC. Even if the DTA does not explicitly say so, it must be understood that both apply as amended, notably by Directive 2007/66/EC. See $n 8$.

${ }^{50}$ Telles, 'Updated Draft Agreement on the UK's withdrawal from the EU [Public Procurement]' (n 30).
} 
reduction of procurement-related red tape; in particular concerning the procurement-specific database e-Certis. ${ }^{51}$ This cooperation is achieved in terms that go beyond the restrictive general collaboration and access to databases defined under Art 7 DTA. This general provision establishes that at the end of the transition period, the UK shall cease to be entitled to access any network, any information system, and any database established on the basis of EU law and imposes on the UK an obligation to take appropriate measures to ensure that it does not access a network, information system, or database which it is no longer entitled to access. By way of derogation from that general rule, probably in order to allow for the completion of ongoing procurement procedures without increased administrative burdens on tenderers and candidates, Art 74 DTA establishes that UK contracting authorities shall have recourse to e-Certis and shall require primarily such types of certificates or forms of documentary evidence that are covered by e-Certis for a period not exceeding 9 months from the end of the transition period in respect of the procedures under Directive 2014/24/EU launched by contracting authorities from the UK before the end of the transition period and not yet finalised on the last day thereof. Although not explicitly stated, access should also be possible to other mechanisms supporting the use of the European Single Procurement Document (ESPD), ${ }^{52}$ at least in what concerns the electronic service currently hosted and offered by the European

\footnotetext{
${ }^{51}$ eCertis is an online database listing the eligibility criteria and documentary evidence needed in each EEA country to take part in public procurement. It supports the operation of a system of self-declarations by economic operators that aims to minimise the documentary requirements associated with cross-border participation in procurement procedures (the ESPD). See http://ec.europa.eu/growth/single-market/publicprocurement/e-procurement/espd/.

52 The ESPD is a self-declaration form used in public procurement procedures by public buyers and businesses in the EU. Before the introduction of the ESPD, companies were required to submit various documents to prove that they fulfil the exclusion and selection criteria of a tender, for example have paid taxes and have not been convicted of criminal activity. Now, companies are able to meet these obligations with a single ESPD selfdeclaration form. The actual documents will only have to be provided by the winner of the tender. This is
} 
Commission..$^{53}$ This is intended as a temporary tool while Member States develop their own national approaches, ${ }^{54}$ but it remains available for any contracting authority in the meanwhile. As such, regarding UK based contracting authorities, access to the service will remain theoretically available for the 9-month window after the end of the transition period during which they are obliged to continue relying on e-Certis.

This is important for two reasons. First, it violates the principle of 'initially subject, always subject' to the "relevant rules". In procedures ongoing beyond the 9-month window of post-Brexit access, it will no longer be possible for UK contracting authorities to use the e-Certis database. This may raise practical issues in terms of information available for the qualification of tenderers. Second, it can potentially impose an asymmetrical burden on UK and EU tenderers, given that EU-based contracting authorities will permanently be under an obligation to have recourse to e-Certis (at least for procurement covered by Directive 2014/24/EU), but only in favour of tenderers from the EU Member States, which the UK will be no longer. Thus, even if EU-based contracting authorities were willing to unilaterally continue to rely on e-Certis for documentation concerning UK-based tenderers (for a period of 9 months post-Brexit, or even longer, and in relation to ongoing or new procurement procedures), this could be of no use to UK-based tenderers if the UK immediately discontinued its cooperation in the running of e-Certis on Brexit day-which seems the likely effect of Art 74 DTA in its

regulated in Art 59 Dir 2014/24. For further details and critical assessment, see P Telles, 'The European Single Procurement Document' (2017) 1 Procurement Law Journal 1-21.

${ }^{53}$ Available at https://ec.europa.eu/growth/single-market/public-procurement/e-procurement/espd en.

${ }^{54}$ For England, Wales and Northern Ireland the Crown Commercial Service published an adaptation of the ESPD called the Standard Questionnaire (SQ), PPN/Action Note 08/16, available at https://www.gov.uk/government/publications/procurement-policy-note-816-standard-selectionquestionnaire-sq-template. Scotland, has adopted instead a model much closer to the ESPD itself, available at https://www.procurementjourney.scot/node/134/. 
current form. Therefore, this is a provision that can create practical problems for the completion of ongoing procurement procedures by EU-based contracting authorities if UK-based tenderers relying on e-Certis are involved, to the likely detriment of UK tenderers. It could be that the UK's continued participation in eCertis as a provider of inputs can be extended beyond Brexit day on the basis of the duty of good faith (Art 4a DTA) or, more generally, for simple practical purposes-as it will be in the UK's interest not to jeopardise the chances of success of UK tenderers in on-going EU business opportunities. However, this is not necessarily a straightforward interpretation of the provision. In our view, the DTA should have foreseen a more active involvement in the UK with e-Certis as a whole, rather than solely as a user of the database.

\subsection{What the DTA does not cover: clear as mud?}

As much as the DTA rules on public procurement go a long way in ensuring maintenance of the status quo during the transition period and a smooth phasing out of compliance with EU law, they also fall short on three aspects that would have required explicit regulation: first, the scope of coverage of the DTA in relation to procurement carried out by the EU Institutions themselves; second, the continued enforcement of the rules on contract modification and termination; and third, the interaction between procurement and other rules.

Perhaps surprisingly, one of the aspects of EU-covered procurement that the DTA seemingly fails to address is the regulation of public procurement carried out by the EU Institutions themselves under their specific rules. ${ }^{55}$ It is important to stress that the Financial Regulation (Arts 119 and 120) only imposes an obligation to admit the participation on non-discriminatory grounds by economic

\footnotetext{
${ }^{55}$ Currently, Regulation (EU, Euratom) No 966/2012 of the European Parliament and of the Council of 25 October 2012 on the financial rules applicable to the general budget of the Union and repealing Council Regulation (EC, Euratom) No 1605/2002, consolidated version available at http://eur-lex.europa.eu/legalcontent/EN/TXT/PDF/?uri=CELEX:02012R0966-20160101\&from=EN. From 1 January 2019, these rules will be replaced by the new Omnibus Regulation. See $\mathrm{n} 8$.
} 
operators covered by the EU Treaties (ie from the Member States), or from third countries with which the EU has a free trade agreement covering procurement, including the WTO GPA (see below, section 4) ${ }^{56}$ Importantly, on Brexit day and for the duration of the transition period, UK-based economic operators will not be directly covered by either of these rules, ${ }^{57}$ or at least not in a straightforward manner.

In our opinion, the DTA does not create an explicit obligation for the EU Institutions to continue treating UK-based tenderers and candidates willing to participate in their procurement procedures in a non-discriminatory manner during the transition period. This is so because, even if the procurement rules of the Financial Regulation and its Implementing Regulation ${ }^{58}$ could be considered covered by the open-ended definition of "relevant rules" in Art 71 DTA when it refers to "any other specific rules of Union law governing public procurement procedures", Art 72(1) would not trigger their application. Indeed, as mentioned above, Art 72(1) mandates compliance with the "relevant rules" in relation to procurement procedures or the performance of framework agreements solely "by contracting authorities or contracting entities from the Member States or the United Kingdom", which

\footnotetext{
${ }^{56}$ Indeed, Art 119 of the Financial Regulation establishes that participation in procurement procedures covered by those rules shall be open on equal terms to all natural and legal persons within the scope of the Treaties and to all natural and legal persons established in a third country which has a special agreement with the Union in the field of public procurement under the conditions laid down in that agreement. In turn, Article 120 of the Financial Regulation further adds that, where the WTO GPA applies, the procurement procedure shall also be open to economic operators established in the states which have ratified that agreement, under the conditions laid down therein.

${ }^{57}$ The same applies under Arts 176 and 177 of the Omnibus Regulation.

${ }^{58}$ Commission Delegated Regulation (EU) No 1268/2012 of 29 October 2012 on the rules of application of Regulation (EU, Euratom) No 966/2012 of the European Parliament and of the Council on the financial rules applicable to the general budget of the Union, consolidated version available at http://eur-lex.europa.eu/legalcontent/EN/TXT/PDF/?uri=CELEX:02012R1268-20160101\&from=EN.
} 
does not include the EU Institutions themselves. This is also not covered by the clause on equal treatment in Art 72(2) DTA, as it solely refers to the procedures referred to in Art 72(1)-ie those carried out by contracting authorities or contracting entities from the Member States or the United Kingdom.

Therefore, the only possibility to establish an implicit non-discrimination obligation incumbent upon the EU Institutions and for the benefit of UK-based economic operators would be to read Art 119 of the Financial Regulation in light of Art 120(1) DTA, whereby "[u]nless otherwise provided in this Agreement, Union law shall be applicable to and in the United Kingdom during the transition period" and Art 120(3) DTA, according to which "[d]uring the transition period, the Union law applicable pursuant to paragraph 1 shall produce in respect of and in the United Kingdom the same legal effects as those which it produces within the Union and its Member States and shall be interpreted and applied in accordance with the same methods and general principles as those applicable within the Union". This could potentially be seen as extending the obligation created by Art 119 of the Financial Regulation on the basis that, during the transition period, UK-based economic operators need to continue to be considered in a situation akin to that of natural and legal persons within the scope of the Treaties or, at least, akin to that of natural and legal persons established in a third country which has a special agreement with the Union in the field of public procurement. However, this would require a contra legem interpretation of Art 72(1) DTA and would rely on an implicit general duty despite a contrary lex specialis, which does not seem the most natural interpretation of Art 120 DTA in relation to Art 72 thereof. Such stretched interpretation of Art 119 of the Financial Regulation in light of Art 120 DTA could be reinforced by the good faith duty of Art 4a DTA but, even then, the existence of a duty of non-discrimination in favour of UK-based economic operators willing to participate in procurement procedures carried out by the EU Institutions may be more a matter of realpolitik than of enforceable legal duties. In that regard it is not possible to conclude with certainty if the explicit omission from the DTA is simply an oversight or evidence of realpolitik already at play even before the transition occurs, as can be inferred from the decision to exclude UK companies from 
participating in the Galileo project. ${ }^{59}$ In either case, an explicit rule in the public procurement chapter of the DTA would have been preferable than the current ambiguity.

The second of the aspects where the DTA rules on procurement should have been explicit in order to avoid interpretive and enforcement difficulties concerns the new rules on contract modification and termination of Arts 72 and 73 of Directive 2014/24/EU and their equivalents in other instruments covered in the "relevant rules". ${ }^{60}$ As mentioned elsewhere, there are no provisions in the DTA about contracts already awarded and under performance ${ }^{61}$ - either for contracts awarded under the "relevant rules", or long-term contracts awarded under previous generations of EU rules and their domestic transposition in the UK that could still be in force (eg private-public partnerships or concession contracts with a long investment cycle). Moreover, the domestic transposition of those

\footnotetext{
${ }^{59}$ M Hollinger and G Parker, 'UK cries foul over exclusion from EU satellite plan', Financial Times, 26 March 2018, available at https://www.ft.com/content/ff5bbc0c-3120-11e8-b5bf-23cb17fd1498.
}

${ }^{60}$ The 2014 EU public procurement package introduced new rules on modification and termination of public contracts that go beyond pre-existing case law. The need for these rules largely derives from the fact that the modification of an existing contract could be an easy way to favour contractors, which led the Court of Justice to equate substantial modifications of existing contracts with a (notional) illegal direct award of a contract for the relevant modification. The doctrine on modification of contracts and its limits has recently been recast in the Judgment of 7 September 2016, Finn Frogne, C-549/14, EU:C:2016:634. Similarly, contracts illegally awarded must be terminated to ensure the effectiveness of the EU public procurement rules. See eg Judgment of 19 June 2008, pressetext Nachrichtenagentur, C-454/06, EU:C:2008:351. Modification and termination of contracts are now explicitly regulated, eg in Arts 72 and 73 Dir 2014/24.

${ }^{61}$ Telles, 'Some thoughts on the procurement elements of the EU's Draft Withdrawal Agreement' (n 28); the implication then extracted was that "the conclusion is that performance of contracts post-withdrawal will be subject to the national laws only thus meaning Articles 70 to 73 of Directive 2014/24/EU on contract performance will no longer apply". Here, we aim to introduce some additional nuance in the analysis, although the main practical conclusion remains. 
rules by means of regs 72 and 73 of the Public Contracts Regulations 2015 can be subject to legal reform post-Brexit, ${ }^{62}$ and their existence cannot be taken as a sufficient guarantee of permanence of those constraints on the modification of contracts during their term. This raises the difficulty of establishing the extent to which the rules on contract termination and modification in the Directive are incorporated into contracts awarded under their rules at the point of formation, or whether the operative rules on which Arts 72 and 73 of Directive 2014/24/EU are founded-which were first declared by the Court of Justice as requirements derived from the general principles of EU procurement law ${ }^{63}$-are applicable in any case in a manner that diminishes the need for the direct application of the more developed rules in the statutory instrument. This can be relevant from a practical perspective if contracting authorities or entities decide to modify existing contracts in ways that would not be allowed under EU law-eg by extending their duration or expanding their scopein particular in order to avoid the tendering of new contracts during the implementation period or close to its expiry, for the strategic reasons hinted at above (section 2.1). In these cases, the applicability or not of the contract modification rules can be very important due to the implicit duty to terminate and retender that derives from the carrying out of illegal contract modifications.

There can be rather valid arguments on both sides of a dispute on this point of law, and part of the legal solution would depend on English contract law as interpreted in view of the European Union (Withdrawal) Act $2018^{64}$ and its provisions on retained EU law and retained EU case law - which creates significant uncertainty in itself, and which can be compounded by additional uncertainty derived from the as yet unclear operation of the preliminary reference mechanism during the transition period and beyond. The likelihood of the rules on contract modification and termination of

\footnotetext{
${ }^{62}$ Domestically, such modification would be governed by the requirements of the European Union (Withdrawal)
} Act 2018, SI 2018 No. 16.

${ }^{63}$ See $n 60$.

${ }^{64}$ See $n 62$. 
Arts 72 and 73 of Directive 2014/24/EU applying as they are seems slim and, in that regard, the DTA could also have been more explicit. It could be that the EU and the UK wanted to limit the DTA to the procurement process and willingly avoided any issues of contract execution that could generate legal disputes well beyond the cut-off date of the end of the transition period. In that case, more clarity would have been preferable to the current uncertainty. Conversely, it could be that it was assumed that the rules on contract modification and termination were considered covered by the definition of "relevant rules" in Art 71 DTA and engaged by the fact that the relevant procurement procedure was subjected to those rules in the tendering phase, but this is by no means a straightforward reading of Art 72 DPA. Thus, also in this case, more clarity would have been welcome.

Finally, a third aspect that is rather unclear in the DTA rules on procurement concerns its interaction with other sets of rules. In particular, the uncertainty comes from the mention in Art 72(5) DTA that that article "shall not affect Union or United Kingdom rules on customs, movement of goods, provision of services, recognition of professional qualifications or intellectual property". Exactly how public procurement rules aimed at resolving the practicalities of ongoing tender procedures during the transition period could affect those other sets of rules is less than clear. One possibility would be that, were the EU and the UK to agree on transition rules that deviated from status quo rules in any of those fields, and given that EU procurement law is designed to work in a coordinated manner with current EU law, the purpose of Art 72(5) DPA would be to ensure that the rules in the DPA rather than those in pre-transition EU (and UK) law are applied in a procurement context. However, this is not necessarily apparent from Art 72(5), as it does not refer to rules on those issues in other titles or chapters of the DPA, but rather to rules on other issues under EU and UK law. Thus, some other explanation of the need for Art 72(5) DPA may be necessary, but it is difficult for us to find one. We could speculate on whether the provision aims to limit the possibility for procurement rules (or, rectius, their enforcement) to act as a lever to force market opening beyond explicit pre-transition EU 
and UK law in other areas. ${ }^{65}$ However, such an approach would not hold water because the interpretation of EU public procurement law is ultimately the exclusive competence of the Court of Justice and a provision such as Art 72(5) DPA would most likely reveal itself inoperative in trying to reign in a pro-integrative interpretation of EU public procurement by the Court-either in the context of a dispute involving the UK or not, ${ }^{66}$ provided that the ruling by the Court of Justice had to be taken into account for the purposes of enforcing the "relevant rules" during the transition period. On the whole, thus, Art 72(5) DTA seems largely redundant and we wonder if its inclusion may be creating more doubts than it aimed to avoid.

\section{Post-Brexit 'Internal' EU-UK Procurement: Priorities \& Challenges}

After having assessed the procurement rules of the DTA in the previous section, we now move to the unresolved issues concerning the future EU-UK relationship. Part of the difficulties with the rules in the DTA implicitly derive from the fact that they seem to assume a 'transition into the void'. Their design is such as to establish an absolute cut-off date ${ }^{67}$ after which EU-UK trade in procurement becomes unregulated. Of course, this logic makes sense in the context of the sequenced negotiations that ensue from Art 50 TEU. However, in case the EU and the UK reach a trade agreement that regulates their future trade relationships and includes procurement (a future 'EU-UK FTA'), a reform

\footnotetext{
65 Indeed, the Court of Justice has a track record of using procurement rules to infer more general Treaty-based obligations. For discussion, see S Treumer and E Werlauff, 'The Leverage Principle: Secondary Community Law as a Lever for the Development of Primary Community Law' (2003) 28(1) European Law Review 124-133.

${ }^{66}$ Indeed, the expansion could eg take place as a result of the answer to a preliminary reference originating in a different jurisdiction.

${ }^{67}$ Or rather a series of them: ie either end of the transition period, or completion of the relevant on-going procedure, or termination of the relevant framework agreement, or adjudication of the relevant legal dispute, or nine months after expiry of the transition concerning some aspects of e-Certis cooperation.
} 
of the DTA may be necessary to ensure transition into the procurement rules of such agreement, rather than into the void-or, in different terms, to avoid the need for 'two consecutive transitions'. In that regard, addressing the specific issues identified above (see section 2.2) may be desirable (eg to avoid uncertainty as to the applicability of constraints on contract modification or termination for contracts awarded under different transitory regimes). In this section, we concentrate on the analysis of other areas that require careful consideration in the context of designing the future regime for EUUK trade in public procurement: substantive convergence in EU-UK regulation of procurement (3.1), transparency of procurement opportunities (3.2), mutual recognition of standards and use of common technical specifications (3.3), administrative cooperation stricto sensu (3.4), cross-border procurement cooperation (3.5), remedies (3.6) and the instrumentalization of procurement (3.7).

Unavoidably, some of these issues are interdependent with the EU's and the UK's future position within the WTO GPA (discussed below, section 4), which can predetermine a regulatory baseline that limits the possibilities of future changes-in particular in the direction of de-regulation of procurement. ${ }^{68}$ However, in this section, we discuss those issues on the assumption that they are compatible with the EU's and UK's WTO GPA position because they are included in the context of what could be termed a GPA plus agreement that generates no issues of incompatibility with strict WTO GPA obligations. ${ }^{69}$ It is also worth noting that some of the issues discussed here concern the

\footnotetext{
${ }^{68}$ As discussed in detail in our previous piece ( $\mathrm{n}$ 11). As mentioned above (section 1 ), we acknowledge that, as things stand, an agreement on a future EU-UK FTA (or its main characteristics) may be necessary in order to complete the UK's WTO GPA accession and the adjustment of the EU's schedules, which already creates a 'chicken and egg' problem. However, for the purposes of keeping some order in our analysis, we decided to complete the analysis of 'internal' procurement before proceeding to assess 'external' procurement issues below (section 4).

${ }^{69}$ In that regard, it is important to stress that given the way in which the agreement operates, which does not include a strict most favoured nation obligation (which only exists for developing countries under Art V), the WTO GPA does not oppose more intense bilateral collaboration amongst its signatories. This is clear from the
} 
interaction of procurement rules with (potentially) new rules in other areas, such as rules on customs, movement of goods, provision of services, recognition of professional qualifications or intellectual property (see above 2.2 re Art 72(5) DTA). This can create a series of 'chicken and egg problems' to the extent that the retention or development of rules on eg recognition of standards for the purposes of procurement ${ }^{70}$ may need to be dependent on more general rules on recognition of standards, whereas the latter may not exist depending on the 'intensity' of the free trade agreement reached by the EU and the UK in areas other than procurement. While acknowledging this, the discussion in this section will not take into account implications beyond the area of public procurement.

\subsection{Substantive convergence in EU-UK regulation of procurement}

One of the counter-intuitive aspects of discussing a future EU-UK FTA covering procurement concerns the extent to which it will be able to ensure substantive convergence in the regulation of procurement in the EU and the UK. As is obvious, given the UK's transposition of the $2014 \mathrm{EU}$ public procurement package and, more generally, the full application of the "relevant rules" during the transition period (see above 2), the starting point is one of full harmonisation and the EU-UK FTA can seemingly only foresee two dimensions: ensuring future convergence regarding the regulation of new issues and limiting regulatory divergence if either of the parties seeks to deviate from the initially fully harmonised standards. This makes the dynamics completely opposite to that of regulatory

conclusion of recent trade agreements including 'GPA plus' procurement obligations between the EU and Canada, or the EU and Singapore. See EU-Canada Free Trade Agreement, available at http://www.consilium.europa.eu/en/press/press-releases/2016/10/28/eu-canada-trade-agreement/; and EUSingapore Free Trade Agreement, available at http://trade.ec.europa.eu/doclib/press/index.cfm?id=961.

${ }^{70} \mathrm{EU}$ procurement rules contain specific rules on the use of technical standards for the purposes of specifying the technical characteristics of the goods, works or services to be procured. However, the specific procurement rules are coordinated with and cannot disapply the general EU rules on standardisation, as demonstrated in the Judgment of 14 June 2007, Medipac-Kazantzidis, C-6/05, EU:C:2007:337. 
cooperation and convergence clauses in other FTAs covering procurement, which can be problematic enough. While in most FTAs regulatory convergence is aspirational and developments in that area tend to generate advantages for both parties, in an EU-UK FTA context, making space for regulatory divergence will tend to create increased costs for relevant parties (most likely, for economic operators) and can result in strict losses of competitiveness of tenderers and efficiency of the procurement function. This is thus something to consider carefully and it would not seem unreasonable to expect a future EU-UK FTA to crystallise the regulatory status quo and prevent regulatory divergence except in issues to be regulated afresh-where convergence (and mutual recognition), rather than uniformity may suffice. Or, in other words, it would not be unreasonable for the parties to agree that a future EU-UK FTA requires indefinite continued application of the EU's procurement rules in the UK-which would de facto make the rules of the DTA (in particular Art 72) redundant if there were no gaps in temporal coverage between the two agreements.

However, this may be a slightly over-simplified view of things. Given the recent major reform of EU public procurement rules through the 2014 package ${ }^{71}$ and the scarcity of case law interpreting them that will likely be generated by the end of the transition period initially foreseen in the DTA (31 December 2020), what exactly full initial harmonisation means may require some further thought. Given the UK's reluctance to accept a binding obligation to follow future Court of Justice case law, ${ }^{72}$

\footnotetext{
${ }^{71}$ The 2014 package replaced the earlier 2004 package and introduced significant changes aimed at providing more flexibility. For extended discussion of this reform and its implications, see the contributions to GS $\varnothing$ lykke and A Sanchez-Graells (eds), Reformation or Deformation of the EU Public Procurement Rules (Edward Elgar, 2016).

${ }^{72}$ See section 6(2) of the European Union (Withdrawal) Act, which establishes that: "a court or tribunal may have regard to anything done on or after exit day by the European Court, another EU entity or the EU so far as it is relevant to any matter before the court or tribunal". Even if this is an improvement over the equivalent clause in the draft Bill, which read "A court or tribunal need not have regard to anything done on or after exit day by
} 
and the importance of the Court of Justice's case law in shaping public procurement rules and developing new doctrines on the scope of application of the rules, ${ }^{73}$ ensuring commonality of the law in the books ${ }^{74}$ will hardly ensure actual regulatory harmonisation. In that regard, an obligation for the UK to continue following the entirety of the EU acquis may be necessary and this may well require continued collaboration between the European Commission and the UK Government in order to ensure a commonality of approach to the reception and application of new developments in the Court of Justice's case law. Finding ways to do so may be difficult, but the need for close collaboration can only be intensified by the recent increased reliance on soft law by the European Commission, which has committed to limiting future reforms of EU procurement law and to rather try to maximise the effectiveness of the current rule book through policy interventions. ${ }^{75}$ Barring any return to a strategy of developing EU procurement policy and practice through hard law, ${ }^{76}$ this approach is bound to result

the European Court, another EU entity or the EU but may do so if it considers it appropriate to do so", it still falls short from guaranteeing the future application of the case law of the Court of Justice in the UK.

${ }^{73}$ The relevance of case law in the interpretation and application of the EU public procurement rules can hardly be overstated. For example, in the period 2015-2017, the Court issued over 40 judgments of great relevance, sometimes creating new rules and exemptions. For in-depth discussion, see A Sanchez-Graells and C De Koninck, Shaping EU Public Procurement Law. A Critical Analysis of the CJEU Case Law 2015-2017 (Kluwer, 2018).

${ }^{74}$ This problem is hardly new. R Pound, 'Law in Books and Law in Action' (1910) 44 American Law Review 12. For a recent reflection, see J-L Halperin, 'Law in Books and Law in Action: The Problem of Legal Change' (2011) 64 Maine Law Review 45.

75 See the European Commission's October 2017 procurement package, available at http://europa.eu/rapid/press-release IP-17-3543 en.htm, and in particular the Communication on Making Public Procurement work in and for Europe, $\operatorname{COM(2017)} 572$ final, available at http://eur-lex.europa.eu/legalcontent/EN/TXT/?uri=COM:2017:572:FIN.

${ }^{76}$ It is worth keeping in mind that this approach was adopted by the Junker Commission, which will end its mandate in Nov 2019-ie a full year before the transition ends, or even longer before that in case of any 
in relevant changes in EU procurement law in action, and this is where regulatory convergence may well need to concentrate.

\subsection{Transparency of procurement opportunities}

A second important aspect concerns the transparency of procurement opportunities, which goes beyond the relatively simple issue of ensuring on-line publication of contract notices or equivalent future business opportunity notices in a website in a language of common use in international trade (ie English). ${ }^{77}$ Whether the UK will or could have access to the Official Journal of the European Union to publish such notices, or the UK's own database (Contracts Finder) ${ }^{78}$ will remain open access and free to use can be important elements in ensuring continued transparency of procurement opportunities. However, there are more relevant issues of detail that can determine the actual transparency of such notices. The current EU regime is underpinned by the use of a Common Procurement Vocabulary $(\mathrm{CPV})^{79}$ that aims to ensure that the procurement opportunities that are publicised can be properly identified by economic operators active in the relevant field. Compliance with the CPV may be far from perfect, but it is actively monitored by the European Commission and

extension. It is therefore not unthinkable that the current approach is a temporary measure before renewed legal framework changes in the mid 2020s.

77 On the continued relevance of the English language for the operation of the EU, despite the UK withdrawal and the implications this may have for the status of English as an official language of the Union, see 'Britain is leaving the EU, but its language will stay', The Economist, 13 May 2017, available at https://www.economist.com/news/europe/21721861-despite-jean-claude-junckers-joke-anglophones-shouldrest-easy-britain-leaving-eu-its.

\footnotetext{
${ }^{78}$ https://www.gov.uk/contracts-finder.

${ }^{79}$ See above $\mathrm{n} 37$ and accompanying text.
} 
economic agents, and lack of compliance can carry relevant legal consequences ${ }^{80}$ Therefore, future collaboration on transparency of procurement opportunities should not only concentrate on the medium for such transparency and other important issues concerning metadata and the facilitation of automated treatment of information, but also include relevant technical aspects ensuring homogeneity of classification and the interconnectedness and interoperability of transparency mechanisms.

\subsection{Mutual recognition of standards and use of common technical specifications}

Similar issues of compatibility and mutual recognition arise concerning the use of a common approach to technical standards and specifications. The relevance of neutrality and transparency in the setting of technical specifications in the context of competitive procurement can hardly be overstated ${ }^{81}$ However, it is also clear that this is not an issue of exclusive relevance in the field of public procurement, but rather more generally one of the key issues in ensuring continued 'frictionless trade' due to the importance of standardisation as a mechanism to prevent non-tariff barriers to free trade. ${ }^{82}$

\footnotetext{
${ }^{80}$ More recently, in the context of the EEA but with references to the relevant Court of Justice's case law, see the EFTA Court's Judgment of 21 March 2018 in EFTA Surveillance Authority v Norway (Kristiansand's parking), case E-4/17, available at http://www.eftacourt.int/uploads/tx nvcases/4 17 Judgment.pdf.

81 Indeed, setting discriminatory technical specifications has traditionally been one of the ways in which contracting authorities have tried to favour domestic suppliers. This has resulted in a significant volume of case law concerning technical requirements and the need to ensure their neutrality in order to ensure nondiscrimination. Most recently, this has been the object of the Judgment of 8 June 2017, Medisanus, C-296/15, EU:C:2017:431. For general discussion, see S Arrowsmith, The Law of Public and Utilities Procurement. Regulation in the EU and the UK, 3rd edn, vol 1 (London, Sweet \& Maxwell, 2014) 648 ff; and A Sanchez-Graells, Public procurement and the EU competition rules, 2nd edn (Oxford, Hart, 2015) 327-336.

${ }^{82}$ As an indication of the relevance of standardisation for the functioning of the internal market and the threat that Brexit presents on that front, see the recent report by the Swedish standardisation agency SWEDAC, Brexit
} 
Whether a future EU-UK FTA will include significant rules on harmonisation or mutual recognition of technical standards is beyond the scope of our discussion. However, suffice it to stress here that any deviation from the current rules to the effect of allowing for the existence of parallel EU and UK standards can create a significant administrative burden in the context of public procurement, both for contracting authorities and tenderers.

\subsection{Administrative cooperation}

The need for continued administrative cooperation has probably already emerged from the previous discussion (re substantive convergence, transparency and joint development or mutual recognition of standards), and this can only be emphasised by focusing on administrative collaboration stricto sensu for the running of procurement procedures.

One of the areas of particularly intense (and long-lasting) commitments in the DTA concerns the continued use of e-Certis (and implicitly, of the ESPD and its temporary centralised support through the European Commission's electronic service) by the UK for a period of 9 months exceeding the end of the transition period (see above 2.1). This can only be seen as a recognition of the relevance of the system of self-certification backed up by administrative collaboration in the upkeep of a common database of documents relevant for the exclusion and qualitative selection of candidates and tenderers in public procurement procedures covered by current EU and UK rules. The disconnection of the UK from the e-Certis database so quickly after the end of the transition will affect contracting authorities in the UK and the rest of the EU. As for the first, they will not be able to rely on the e-Certis system beyond the 9-month window even for procedures that are already ongoing. As for the latter, if they have UK-based tenderers participating in a procedure that is on-going at the end of the transition period, they will not be able to rely on access to such tenderers' documentation via the e-

and technical regulations for goods, 1 December 2017, available at https://www.marknadskontroll.se/wpcontent/uploads/2018/02/Brexitrapport-ENG-180201.pdf. 
Certis system-and this does not necessarily apply only to procedures lasting more than those 9 months, as the day for the disconnection of the UK as a provider of input into eCertis is not clear and could be exactly that of the end of the transition period (see above 2.1). If for most procurement procedures this may not be a significant problem, it is potentially problematic for framework agreements with call offs where the contracting authority may wish to check ongoing compliance by UK-based contractors. In this context, it is evident that UK-based undertakings could be disadvantaged as they would have to provide documentary evidence whereas others might not.

The importance of such a system of self-certification backed up by a common database is unlikely to diminish in any meaningful way in the future, and a potential opening of e-Certis to nonEU States in the context of FTAs ${ }^{83}$ or the WTO GPA could only increase it. Therefore, for all its flaws and practical difficulties, continued collaboration in the running and use of e-Certis by both the UK and the EU would be beneficial in terms of keeping the costs of red tape associated to procurement as low as possible.

Beyond the above, administrative cooperation would also be necessary in the area of technical standardisation (see above 3.3 ), ${ }^{84}$ as well as in relation to other mechanisms aimed at reducing red tape in procurement or at facilitating the roll-out of policies aimed at ensuring compliance with certain environmental and quality control standards, as well as promoting the use of labels in procurement. ${ }^{85}$ Cooperation will be equally relevant in the context of the implementation of

\footnotetext{
${ }^{83}$ On the relevance of e-Certis within the context of the EU-Canada FTA (CETA), see eg Global Affairs Canada, European Union Government Procurement Guide for Canadian Businesses, available at http://publications.gc.ca/collections/collection_2017/amc-gac/FR5-109-2017-eng.pdf.

${ }^{84}$ See also Art 44 Dir 2014/24/EU.

${ }^{85}$ The use of labels as mechanisms of certification of compliance with technical standards or other requirements (eg environmental standards, such as 'organic', or social requirements, such as 'fair trade') is increasingly important in the area of public procurement and received a significant push in the 2014 EU public procurement
} 
current strategic priorities concerning the use of procurement for environmental or social goals (but see below, 3.7), as well as the professionalisation of the procurement task force, ${ }^{86}$ or in the development of networks for knowledge exchange eg in relation to large infrastructure projects. ${ }^{87}$ If Brexit were to put a halt to these initiatives, the potential gains derived from on-going collaboration would likely be lost. Therefore, seeking ways of maintaining administrative collaboration seems like another area of priority for a future EU-UK FTA covering procurement matters.

\subsection{Cross-border procurement cooperation}

Another area that may deserve careful consideration concerns cross-border cooperation in the context of specific procurement projects (where contracting authorities of different Member States can work together for a joint or collaborative procurement), as well as for the cross-border provision of centralised purchasing services or supplies by central purchasing bodies (CPBs) (which allows contracting authorities of a Member State to benefit from the centralised purchasing carried out by the CPB of a different Member State $)^{88}$ This is a novel area of regulation in the 2014 EU public

rules, which consolidated the previous approach in the Judgment of 10 May 2012, Commission v Netherlands (fair trade coffee), C-368/10, EU:C:2012:284. See Arts 43 and 62 Dir 2014/24/EU.

${ }^{86}$ European Commission, Recommendation on the professionalisation of public procurement: Building an architecture for the professionalisation of public procurement, C(2017) 6654 [2017] OJ L 259/28, available at http://eur-lex.europa.eu/legal-content/EN/TXT/?uri=CELEX:32017H1805.

${ }^{87}$ European Commission, Communication on Helping investment through a voluntary ex-ante assessment of the procurement aspects for large infrastructure projects, $\operatorname{COM}(2017) 573$, available at http://ec.europa.eu/docsroom/documents/25613.

${ }^{88}$ See Arts 37 to 39 Directive 2014/24/EU. See also A Sanchez-Graells, 'Collaborative Cross-Border Procurement in the EU: Future or Utopia?' (2016) 1 Procurement Law Journal 11-37; and ibid, 'Is Joint Cross-Border Public Procurement Legally Feasible or Simply Commercially Tolerated?: A Critical Assessment of the BBG-SKI JCBPP Feasibility Study' (2017) 12(2) European Procurement \& Public Private Partnerships Law Review 97-111. 
procurement package that relies on the common regulatory baseline across the EU Member States (above, 3.1) to allow them to enter into specific arrangements to carry out joint collaborative procurement, either on an ad hoc basis or in a more permanent manner. The UK public sector has been a pioneer-in particular in the context of healthcare procurement ${ }^{89}-$ so there could be significant potential for cross-border collaboration involving the UK (eg but not limited to with Ireland) in case regulatory divergence (above 3.1) created obstacles in the organisation of collaborative crossborder procurement. Therefore, this is another area of relevance for a future EU-UK FTA covering procurement.

\subsection{Remedies}

If the content of the DTA (see Art 73) is a useful indication of the priorities of the EU and the UK in the regulation of procurement matters, this is another area of high priority for a future EU-UK FTA covering procurement. However, that the system of remedies has a strong connection with the disputed role of the Court of Justice post-Brexit, this can also constitute a stumbling block for a future agreement. There is not much that can be said at this stage. However, it can be stressed that a WTO GPA-compliant remedies system would not look too different from the existing EU requirements and that any reductions in current procedural guarantees can have detrimental effects for the UK procurement system as a whole. ${ }^{90}$ Moreover, it is worth bearing in mind that there is an emerging domestic discussion about the unfitness for purpose of the UK's procurement remedies system and the possible development of a tribunal-based remedy avenue, ${ }^{91}$ which could be an important determinant of the

89 See for example the participation of NHS Commercial Solutions in the HAPPI Project, http://www.commercialsolutions-sec.nhs.uk/page.php?pid=1330.

${ }^{90}$ As previously stressed in Telles \& Sanchez-Graells (n 11) 29-30.

${ }^{91}$ This was the content of an event of the Procurement Lawyers' Association on 17 January 2018 in which one of the authors participated, where three potential options were discussed: the creation of a specialised tribunal, the maintenance of the current court-based system, and the restriction of the system to judicial review based 
UK's position in any future negotiations on this point. Suffice it to stress the relevance of effective remedies in the context of any future EU-UK FTA covering procurement.

\subsection{Instrumentalization of procurement}

A final point to mention concerns the trade implications of the potential instrumentalization of procurement as a tool of industrial policy (ie as a mechanism for the award of State aid, as a means of financial support of chosen domestic industries), either directly, or as a result of some types of smart procurement strategies (ie social procurement, including that seeking to enforce labour standards or to deploy employment policies via public contracts) with strong elements of local preference. In that regard, the interaction of public procurement and State aid rules is bound to attract significant attention. ${ }^{92}$ The current position under EU law is that compliance with EU public procurement rules excludes the existence of State aid ${ }^{93}$ which comes to add to the relevance of ensuring substantive convergence in the regulation of procurement in the UK and the EU post-Brexit (above, 3.1). This will create a double relationship of interdependence between public procurement and State aid control in any future EU-UK FTA, as it will also have to be coordinated with the potential exclusion of tenderers or tenders that have benefitted from State aid in the context of a system to prevent dumping. However, exploring these implications exceeds the possibilities of this paper.

on public law grounds only. Participants overwhelmingly favoured the possible creation of a specialised tribunal. A note of the proceedings should be soon published in https://www.procurementlawyers.org.uk/.

${ }^{92}$ An issue only touched in passing by the House of Lords European Union Committee in its Report on Brexit: competition and State aid on the basis of an assumed compliance with EU public procurement rules, available at https://publications.parliament.uk/pa/ld201719//dselect/ldeucom/67/67.pdf.

${ }^{93}$ European Commission, Notice on the notion of State aid as referred to in Article 107(1) of the Treaty on the Functioning of the European Union, C/2016/2946 [2016] OJ C 262/1, available at http://eur-lex.europa.eu/legalcontent/EN/TXT/?uri=uriserv:OJ.C .2016.262.01.0001.01.ENG\&toc=OJ:C:2016:262:TOC. 


\section{4. 'External' EU and UK Procurement: Quo Vadis WTO GPA?}

Already at the early stages of the Brexit negotiations, the UK made clear its intention of retaining access to WTO GPA procurement markets as a key element of its future trade strategy post-Brexit, ${ }^{94}$ and sought the EU's collaboration to that effect. ${ }^{95}$ After some initial confusion, ${ }^{96}$ and as we already argued elsewhere, ${ }^{97}$ it became uncontroversial that the UK would need to seek fresh accession as a member in its own right to the WTO GPA post-Brexit. ${ }^{98}$ It was also clear that the EU would need to adjust its commitments under the relevant schedules, and that there is a commonality of interest between the UK and the EU in presenting a joint front to other GPA parties. These needs led to the UK's application for accession to the WTO GPA in June 2018 (see above, section 1), which has resulted in a request for additional information by the WTO government procurement committee, which seeks to gain more detailed knowledge of the UK's market access commitments, its EU withdrawal agreement, including timelines that would apply to the WTO GPA, and the UK's plans for domestic procurement legislation. ${ }^{99}$ What remains unclear at this stage (August 2018), however, is the extent to which the EU and the UK will face the need to engage in significant negotiations-and potentially

${ }^{94}$ Department for International Trade, Preparing for our future UK trade policy, October 2017, available at https://www.gov.uk/government/publications/preparing-for-our-future-uk-trade-policy; and Trade White Paper: Preparing for our future UK trade policy - government response, January 2018, available at https://www.gov.uk/government/uploads/system/uploads/attachment data/file/671953/Trade White Paper response FINAL.pdf.

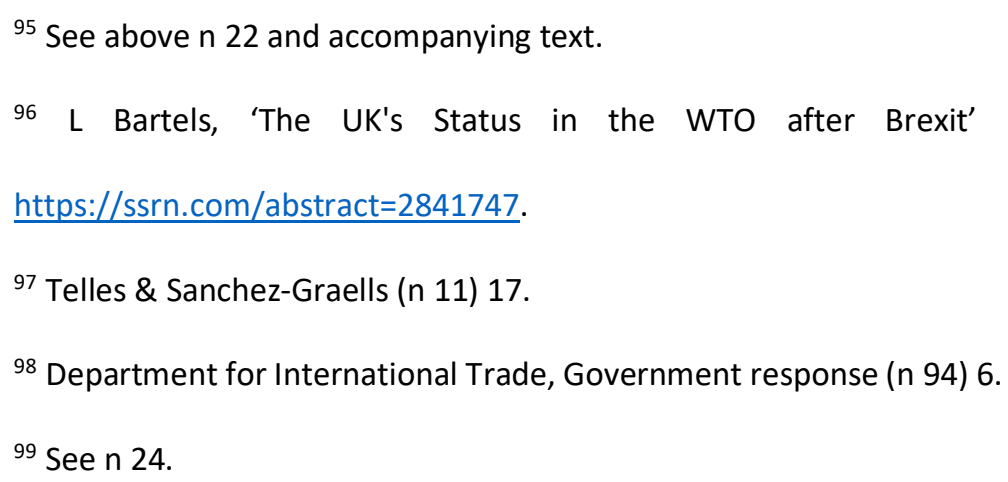


make significant concessions-in order to retain access to the WTO GPA public procurement markets. ${ }^{100}$ An element that can play a role in this regard concerns the type of accession process to which the UK can be subjected, which is yet to be determined, despite the UK's representations concerning the urgency of agreement upon the terms of its membership in order to ensure its continued participation in the WTO GPA after Brexit.

The regular process for a prospective party to join the GPA starts by the WTO member assuming the position of observer in preparation to submit their offer. The actual accession is done by submission of an offer, describing coverage of entities and contracts and constituting the Appendix I offer or coverage offer. ${ }^{101}$ If applicable to the UK, this process raises significant difficulties. This is due to the need to have a coordinated approach with the EU regarding the coverage offer and the challenges arising from trilateral negotiations between the UK, the EU and each of the other GPA signatories. Even if, as part of the DTA, the UK is able to negotiate, sign and ratify its own trade deals during the transition period subject to their entering into force only after the expiry of that period; ${ }^{102}$ it is likely that the UK will only be able to submit a clearly defined coverage offer once it reaches an agreement with the EU on the scope of coverage of their bilateral future FTA-of which the 'split' of pre-Brexit WTO GPA commitments may become part and parcel. This creates a complex situation

\footnotetext{
${ }^{100}$ The remainder of this section re-elaborates our initial views in light of the (limited) developments to date; see Telles \& Sanchez-Graells (n 11) 18-19.

${ }^{101}$ C Yukins \& J Schnitzer, 'GPA Accession: Lessons Learned on the Strengths and Weaknesses of the WTO Government Procurement Agreement' (2015) 7 Trade Law \& Development Journal 89, available at https://ssrn.com/abstract=2749889; and R Anderson \& AC Müller, 'The revised WTO Agreement on Government Procurement (GPA): Key design features and significance for global trade and development' (2017) WTO Staff Working Paper, No. ERSD-2017-04, available at http://hdl.handle.net/10419/152257.

${ }^{102}$ European Commission, Fact Sheet: Questions \& Answers: Publication of the draft Withdrawal Agreement between the European Union and the United Kingdom, available at http://europa.eu/rapid/pressrelease MEMO-18-1361 en.htm.
} 
because any delay in gaining access to the WTO GPA beyond the expiry of the transition period foreseen in the DTA would imply that the UK would be out of the WTO GPA at least temporarily, even though it may or may not be bound to grant market access to the undertakings of WTO GPA members under its current national rules. ${ }^{103}$ Whether the UK will be able to gain access to the WTO GPA for the 'day after Brexit' by itself depends on the set of circumstances applicable to its accession. As argued by the authors in detail elsewhere, ${ }^{104}$ it is conceivable that the UK accession to the WTO GPA follows one of three distinct paths.

First, that it will keep its current commitments and all WTO GPA parties ${ }^{105}$ (EU included) agree to it, making the change in coverage notification mentioned above a mere formality. ${ }^{106}$ In effect, this would not be different from the view taken by the European Commission on Greenland's withdrawal from the European Economic Community in 1983. ${ }^{107}$ Depending on the timing of this process and whether it is completed by the end of the transition period agreed between the EU and the UK under the DTA (or any extension thereof), there could be some transitional issues as the UK could be

103 This would be the result of retaining the current text of reg 25 PCR2015, which transposes Art 25 of Directive 2014/24/EU, and establishes that "In so far as they are covered by Annexes 1, 2 and 4 to 7 to the EU's Appendix 1 to the GPA and by the other international agreements by which the EU is bound, contracting authorities shall accord to the works, supplies, services and economic operators of the signatories to those agreements treatment no less favourable than the treatment accorded to the works, supplies, services and economic operators of the EU". For discussion of this issue, see Telles \& Sanchez-Graells (n 11)15-16.

104 Telles \& Sanchez-Graells (n 11) 18-19.

${ }^{105}$ Currently the agreement has 19 parties, covering 47 WTO members, including the EU and its 28 Member States with a further 10 observers in the process of accession.

${ }^{106}$ Wang (n Error! Bookmark not defined.) 47-48 is of a similar opinion, although with a more cautious view on the probability of other parties demanding compensation or re-negotiation; and Arrowsmith, Consequences of Brexit in the Area of Public Procurement (n 18) 32.

${ }^{107}$ Commission, Status of Greenland: Commission opinion, COM (83) 66 final, Annex A, p.22. 
temporarily out of the WTO GPA before the accession is complete. Taking into account the UK's procurement legislation is already GPA-compliant, in a best-case scenario (no opposition from other WTO GPA parties) the accession should be short and straightforward. However, this seems very unlikely.

Second, the UK may wish to depart from its current commitments and amend its schedule of coverage. ${ }^{108}$ This would amount to a new offer and implies a full accession process with all the risks (and delays) it entails. ${ }^{109}$ As a means of comparison, even a fairly quick accession process like that of New Zealand took 3 years, ${ }^{110}$ and it did not include the added complexity of requiring another WTO GPA member to change its commitments as well—which the EU would have to do in this scenario. ${ }^{111}$ The likelihood of consultation or arbitration with one or more WTO GPA parties is reasonable. Furthermore, this scenario would also generate difficulties for the conclusion of the bilateral EU-UK FTA, in particular if the UK's attempt to alter its WTO GPA coverage is linked to an attempt to reduce coverage of the procurement currently covered by the EU rules.

Third, the UK may want to fully renegotiate its schedule of coverage, perhaps along the lines of a GPA plus model, ${ }^{112}$ or modelled after existing trade agreements which cover procurement in more detail such as the Comprehensive Economic and Trade Agreement (CETA) between the EU and

\footnotetext{
${ }^{108}$ As suggested by Wang (n Error! Bookmark not defined.) 45-46.

109 On the details of the process and documents required see WTO, General Overview of WTO Work on Government Procurement, available at https://www.wto.org/english/tratop e/gproc e/overview e.htm, and Yukins \& Schnitzer (n 101).

${ }^{110}$ On New Zealand's accession, J Schnitzer, 'Expanding the Membership of the WTO Government Procurement Agreement: Montenegro and New Zealand Ratifying the Revised GPA' (2015) 5 Public Procurement Law Review NA185-NA188.

${ }^{111}$ As required by Art XIX of the Revised GPA.

112 Arrowsmith, Consequences of Brexit in the Area of Public Procurement (n 18) 56-61.
} 
Canada. ${ }^{113}$ As with the previous scenario, a full accession would be required but with added scope for uncertainty, risk and delays arising from the negotiations.

When the authors first considered the three scenarios, ${ }^{114}$ it was apparent the first was the most straightforward of the three. In the meanwhile, the situation has not changed significantly in terms of the relative desirability of each option, but in practical terms the absolute complexity of the first scenario has increased, in particular in view of the initial reaction of the WTO government procurement committee. Therefore, option 1 is no longer as straightforward as it could have been as other WTO GPA signatories seem willing to use this opportunity to extract additional concessions. There is a risk as time goes on that more current WTO GPA members will take the opportunity to force a deeper renegotiation with the UK and/or the EU, especially if concessions are made in the meantime. However, staying as close as possible to this pathway and seeking a jointly negotiated solution vis-avis the rest of WTO GPA parties may still be the most direct pathway towards UK's access and EU's repositioning within the agreement in the least disruptive manner.

If, on the other hand, the UK tries to deviate from the status quo, the more likely it is that the accession will end up looking as a fresh accession implying long and protracted negotiations with the other WTO GPA parties. This could potentially become a stumbling block in the negotiations with the EU and consolidate the current position that, in the absence of an EU-UK FTA covering procurement and given the non-existence of a 'WTO rules' default position regulating trade through procurement between the UK and third countries, Brexit implies a transition into the void in terms of regulation of international trade in public procurement markets.

\footnotetext{
${ }^{113}$ Agreement text available at https://trade.ec.europa/eu/doclib/docs/2014/september/tradoc 152806.pdf. On the EU's policy on trade agreements covering procurement see, S Woolcock, 'The European Union's Policy on Public Procurement in Preferential Trade Agreements', in M Bungenberg, M Krajewski, C Tams, J Terhechte \& A Ziegler (eds), European Yearbook of International Economic Law, vol 8 (Springer, 2017) 361-380.

${ }^{114}$ Telles \& Sanchez-Graells (n 11) 18-19.
} 


\section{Conclusion}

In the context of a broader critical assessment of the procurement rules in the 2018 DTA agreed in principle by the EU and the UK, this paper has stressed how the DTA is currently aimed at ensuring a cut-off point where EU-UK procurement would become unregulated, and how this can be problematic in the context of the likely need to transition into an alternative regulatory scenario of a future EU-UK FTA covering procurement. In order to avoid 'two consecutive transitions', it seems preferable to ensure the conclusion of the EU-UK FTA within the period of transition covered by the DTA, to amend the latter agreement, and to ensure smooth transition into the future EU-UK FTA.

The paper has also flagged up areas where retaining collaboration and substantive convergence will be determinant of the effectiveness of the procurement function and to retain the economic advantages of 'frictionless trade' in public procurement markets between the EU and the UK. The analysis has shown how it is in the interest of the UK and the EU to seek to crystallise the status quo and to ensure continued compliance with a single set of standards going forward. The disruption that could derive from the absence of an EU-UK FTA covering these areas-either temporarily, or permanently-would imply a significant loss of the economic advantages gained with the creation of the internal market for public procurement.

The value of a joint EU-UK approach has been further emphasised in the context of the UK's need to seek fresh accession to the WTO GPA and in the EU's vested interest in facilitating this process in order to minimise the disruption of its own access to WTO GPA procurement markets, as well as to avoid or minimise the need for further concessions to other WTO GPA signatories in terms of coverage under the relevant schedules. Therefore, on the whole, we cannot but conclude that it is in both the UK's and the EU's interest to reach a future EU-UK FTA that ensures continued collaboration and crystallises current compliance with EU rules, and to build on it to reach a jointly negotiated solution vis-a-vis the rest of GPA parties. 
In our view, this case study of the post-Brexit re-regulation of procurement-related trade between the EU and the UK, and between these and the wider world, can offer valuable insights in other areas of the future EU-UK relationship. Unsurprisingly, given that the negotiations around Brexit are aimed at damage control or minimisation, it should be expected that the value of preserving the status quo as much as possible and the continuation of existing collaborations will be guiding goals in all areas of reorganisation of EU-UK relationships post-Brexit. 